\title{
Aphids associated with papaya plants in Puerto Rico and Florida ${ }^{1,2}$
}

\author{
Alberto Pantoja ${ }^{3}$, Jorge Peña ${ }^{4}$, Wilfredo Robles ${ }^{5}$, \\ Edwin Abreu ${ }^{6}$, Susan Halbert ${ }^{7}$, María de Lourdes Lugo ${ }^{8}$, \\ Elías Hernández $z^{9}$ and Juan Ortiz ${ }^{10}$
}

J. Agric. Univ. P.R. 90(1-2):99-107 (2006)

\begin{abstract}
Aphids associated with papaya plants were collected from two sites in Puerto Rico (Isabela and Corozal) and three farms in Homestead, Florida. Between the two regions, Florida and Puerto Rico, twenty-one species of aphids from 12 genera were identified: Aphis sp., Aphis illinoisensis Shimer, Aphis spiraecola Patch, Aphis gossypii Glover, Aphis craccivora Koch, Aphis iddletonii (Thomas), Aphis nerii Boyer de Fonscolombe, Hyperomyzus carduellinus (Theobald), Hysteroneura setariae (Thomas), Lipaphis pseudobrassicae (Davis), Picturaphis sp., Pentalonia nigronervosa Coquerel, Schizaphis graminum (Rondani), Sarucallis kahawaluokalani (Kirkaldy), Shinjia orientalis (Mordvilko), Schizaphis rotundiventris (Signoret), Toxoptera citricida (Kilkardy), Toxoptera aurantii (Boyer de Fonscolombe), Tetraneura nigriabdominalis (Sasaki), Uroleucon ambrosiae (Thomas), and Uroleucon pseudoambrosiae (Olive). The number of species was greater in Florida $(n=14)$ than in Puerto Rico $(n=11)$. Differences among species were also found between sites in Puerto Rico, with 10 species in Corozal and six in Isabela. Only one species, $A$. illinoisensis, was common at all sites sampled, whereas three additional species, $A$. spiraecola, $A$. gossypii, and $A$. craccivora were collected in both the Corozal, Puerto Rico, and the Florida areas. The difference in species composition between Puerto Rican sites
\end{abstract}

${ }^{1}$ Manuscript submitted to Editorial Board 12 July 2005.

${ }^{2}$ The authors wish to recognize T. Adams and D. Fielding, USDA-ARS, Fairbanks, Alaska, for critical reviews of an earlier version of this manuscript. The research was partially funded by TSTAR Project 93.

${ }^{3}$ Entomologist, USDA-ARS, University of Alaska, Fairbanks, P.O. Box 757200, Fairbanks, AK 99775. Work conducted while at Puerto Rico Agricultural Experiment Station, Corozal, P.R.

${ }^{4}$ University of Florida, TREC, $18905 \mathrm{SW} 280^{\text {th }}$ Street, Homestead, FL 33031.

${ }^{5}$ Former graduate student, Department of Crop Protection, Univ. Puerto Rico, Mayagüez Campus, Mayagüez, PR.

${ }^{6}$ Professor-Entomologist, Department of Crop Protection, Agricultural Experiment Station, Isabela, P.R.

${ }^{7}$ Florida Department of Agriculture and Consumer Services, Gainesville, FL 32611.

${ }^{8}$ Professor-Weed Scientist, Department of Crop Protection, Agricultural Experiment Station, Gurabo, PR.

${ }^{9}$ Visiting Scientist, Colegio Postgrados. Veracruz, Mexico.

${ }^{10}$ Associate Professor, Department of Agricultural Economics and Rural Sociology, Agricultural Experiment Station, Corozal, P.R. 
(Corozal and Isabela) and between localities (Florida and Puerto Rico) is probably associated with differences in agricultural crops or weeds present in each region.

Key words: papaya, aphids, vectors, weeds

\section{RESUMEN}

\section{Áfidos asociados a la planta de papaya en Puerto Rico y Florida}

Se recolectaron áfidos asociados a la papaya en dos lugares en Puerto Rico (Isabela y Corozal) y en tres fincas y un predio en el Centro de Investigaciones de la Universidad de Florida, TREC, en Homestead, Florida. Entre las dos regiones, Florida y Puerto Rico, se recolectaron veintiuna especies de áfidos de 12 géneros: Aphis sp., Aphis illinoisensis Shimer, Aphis spiraecola Patch, Aphis gossypii Glover, Aphis craccivora Koch, Aphis iddletonii (Thomas), Aphis nerii Boyer de Fonscolombe, Hyperomyzus carduellinus (Theobald), Hysteroneura setariae (Thomas), Lipaphis pseudobrassicae (Davis), Picturaphis sp., Pentalonia nigronervosa Coquerel, Schizaphis graminum (Rondani), Sarucallis kahawaluokalani (Kirkaldy), Shinjia orientalis (MordviIko), Schizaphis rotundiventris (Signoret), Toxoptera citricida (Kilkardy), Toxoptera aurantii (Boyer de Fonscolombe), Tetraneura nigriabdominalis (Sasaki), Uroleucon ambrosiae (Thomas), and Uroleucon pseudoambrosiae (Olive). El número de especies de áfidos fue mayor en Florida $(n=14)$ que en Puerto Rico $(n=11)$. En Puerto Rico, se encontraron diferencias en el número de especies por localidad, con 10 especies en Corozal y seis en Isabela. Solo una especie, $A$. illinoisensis, se encontró en todos los campos donde se tomaron muestras, mientras que $A$. spiraecola, $A$. gossypii y $A$. craccivora se recolectaron tanto en Corozal, Puerto Rico, como en Florida. La diferencia en composición de especies entre localidades en Puerto Rico (Corozal e Isabela) y regiones (Florida y Puerto Rico) parece estar asociada con la diversidad de los cultivos agrícolas y especies de malezas presentes.

Palabras clave: papaya, áfidos, vectores, malezas

\section{INTRODUCTION}

In Puerto Rico and Florida, USA, aphids are considered a key pest limiting papaya production (Martorell and Adsuar, 1952; Abreu, 1994). Aphids do not colonize papaya plants and do not directly injure the plants, but several species can be found on papaya plants (Villanueva and Villanueva, 1994; Abreu, 1994; Namba and Kawanishi, 1966; Villanueva and Peña, 1991; Rabara et al., 1996; Vegas et al., 1986; Schaefers, 1969; Pantoja et al., 2002). Aphids are considered a serious threat to papaya production because of their ability to transmit the papaya ringspot virus and the papaya mosaic virus (Adsuar, 1947a, b; Pontis, 1953; Nariani, 1956; Ishii and Holtzmann, 1963; Khurana and Bhargava, 1971; Becerra, 1987; Namba and Higa, 1981; Higa and Namba, 1971).

Worldwide, the presence of viral diseases and their insect vectors is considered the most severe limiting factor for papaya production (Pantoja et al., 2002). Viral infections produce distinct ringspots on fruits, stunting of plants, all of which leads to yield reduction. Chemical control is difficult because aphids transmit the virus in a non-persistent 
manner (Namba and Higa, 1981; Higa and Namba, 1971); thus, virosis can be transmitted by non-colonizing species, and insecticides may not be effective in preventing transmission (Namba and Higa, 1981).

In a review of arthropods associated with papaya worldwide, Pantoja et al. (2002) indicated that little is known about the species of aphids commonly found on papaya in the Americas and the Caribbean Region. Martorell and Adsuar (1952) reviewed the insects associated with papaya in the Antilles and Florida, whereas Wolcott $(1933 ; 1948)$, Martorell (1976), and Abreu (1994) listed 32 species of arthropods associated with papaya in Puerto Rico. However, these reports are based on literature reviews, data from specimens in museums and short term collecting trips rather than from long term field collections. With all the interest in papaya production and insect management studies, there exists a paucity of information on species composition, alternate hosts, sampling techniques, and biology of the aphid vectors affecting papaya in temperate USA and Puerto Rico. The objectives of this study were to identify the aphid species associated with papaya in two geographical areas of Puerto Rico (Isabela and Corozal) and commercial papaya fields in Homestead, Florida; to compare two sampling techniques for aphids (D-Vac versus water pan traps); and to identify weeds commonly found in papaya fields.

\section{MATERIALS AND METHODS}

Puerto Rico: Aphids were surveyed weekly by using water pan traps following the methodology described by Villanueva and Peña (1991) and Robles (2002). Pan traps consisted of a $10.2 \times 10.2-\mathrm{cm}$ polypropylene container filled with water and $1 \%$ soap, with a removable yellow square placed at the bottom of each trap. Traps were placed on a movable support rod in each field. Water pan traps were placed slightly over the plant canopy and adjusted weekly to plant height. Traps were inspected every week and contents of the trap brought to the laboratory for sorting. Semi-commercial papaya plantings of the variety PR-6-65 were established at the Agricultural Experiment Stations in Corozal and Isabela, Puerto Rico. Collecting pans, one trap per row, were placed in the middle of the papaya rows; 20 plants per row were planted according to the recommendations of the Agricultural Experiment Station (1987). Sampling started about seven weeks after transplant (five to seven true leaves) and continued until plantings were removed, approximately 10 to 12 months after transplanting. Sampling began in March 2000 and continued through September 2001. In Isabela the weeds in $1.4-\mathrm{m}^{2}$ plots were identified and the percentage of coverage was calculated. 
Florida: Aphids in papaya plants were sampled by following the methodology described above for water pan traps in Puerto Rico. Sampling began 5 May 2003 and continued through 1 November 2004. A semi-commercial planting at TREC Research Center in Homestead, Florida, and in three commercial papaya fields in the Homestead area were sampled. The variety Red Lady and a local breeding line were used. In addition to the water pan traps, a suction device (D-Vac) was used in an effort to compare the D-Vac with the water pan trap system. Ten randomly selected papaya plants and 10 randomly selected units of $1.4 \mathrm{~m}^{2}$ containing weeds were surveyed every month with a D-Vac. The weed species in the $1.4-\mathrm{m}^{2}$ plots and the percentage of coverage was calculated.

D-Vac sampling time for each papaya plant ranged from 5 to $10 \mathrm{~min}$, depending on the tree height and the number of leaves per plant. Sampling time for each square meter weed-sampling unit was 5 to $8 \mathrm{~min}$. All samples were conducted in the morning. The D-Vac was held at about 1 to $3 \mathrm{~m}$ above ground and pointed toward the apical leaves of the papaya plant. The operator moved clockwise around the plant. The DVAC was pointed towards the ground for weed samplings.

Insect handling: At both localities, arthropods were placed in plastic bags and transported to the laboratory in an ice chest, inspected under a stereoscope, preserved in $70 \%$ alcohol. Alate aphids were identified by S. Halbert.

\section{RESULTS AND DISCUSSION}

Twenty-one species of aphids from 12 genera were identified (Table 1). The number of species collected was greater in Florida $(n=14)$ than in Puerto Rico $(\mathrm{n}=11)$. Differences in species composition were also found between the two sites in Puerto Rico, with 10 species for the Corozal site as compared to six species from Isabela. Only one species, Aphis illinoisensis, was common at all sites sampled (Florida and Puerto Rico), whereas three additional species, $A$. spiraecola, $A$. gossypii, and A. craccivora, were collected at the Corozal and the Florida sites.

All the species collected from Puerto Rico have previously been reported on papaya from the island (Martorell, 1976; Smith et al., 1963; Abreu, 1994). With the exception of seven species from Florida (A. middletonii, Hyperomyzus carduellinus, Hysteroneura setariae, Lipaphis pseudobrassicae, Shinjia orientalis, Schizaphis rotundiventris, Uroleucon pseudoambrosiae), and two species from Puerto Rico (Picturaphis spp. and Tetraneura nigriabdominalis), the remaining specimens collected (Table 1) have been associated with papaya plantings elsewhere (Hernández, 2001; Pantoja et al., 2002; Vegas et al., 1986; Martorell, 1976; Abreu, 1994). Seven of the species reported in this study, A. crac- 
TABLE 1. Aphid species collected with water pan traps at Isabela and Corozal, Puerto Rico, and Homestead, Florida.

\begin{tabular}{lccc}
\hline & \multicolumn{3}{c}{ Puerto Rico } \\
\cline { 2 - 4 } Species & Isabela & Corozal & Florida \\
\hline Aphis illinoisensis Shimer & $\mathrm{P}$ & $\mathrm{P}$ & $\mathrm{P}$ \\
Aphis spiraecola Patch $* 2$ & - & $\mathrm{P}$ & $\mathrm{P}$ \\
Aphis gossypii Glover* & - & $\mathrm{P}$ & $\mathrm{P}$ \\
Aphis craccivora Koch* & - & $\mathrm{P}$ & $\mathrm{P}$ \\
Aphis middleton (Thomas) & - & - & $\mathrm{P}$ \\
Aphis nerii Boyer de Fonscolombe* & - & - & $\mathrm{P}$ \\
Aphis spp. & - & - & $\mathrm{P}$ \\
Hyperomyzus carduellinus (Theobald) & - & - & $\mathrm{P}$ \\
Hysteroneura setariae (Thomas) & - & - & $\mathrm{P}$ \\
Lipaphis pseudobrassicae (Davis) & - & - & $\mathrm{P}$ \\
Picturaphis spp. & - & $\mathrm{P}$ & - \\
Pentalonia nigronervosa Coquerel* & $\mathrm{P}$ & $\mathrm{P}$ & - \\
Schizaphis graminum (Rondani) & $\mathrm{P}$ & - & - \\
Sarucallis kahawaluokalani (Kirkaldy) & - & - & $\mathrm{P}$ \\
Shinjia orientalis (Mordvilko) & - & - & $\mathrm{P}$ \\
Schizaphis rotundiventris (Signoret) & - & - & $\mathrm{P}$ \\
Toxoptera citricida (Kilkardy) & $\mathrm{P}$ & $\mathrm{P}$ & - \\
Tox. aurantii (Boyer de Fonscolombe)* & $\mathrm{P}$ & $\mathrm{P}$ & - \\
Tetraneura nigriabdominalis (Sasaki) & $\mathrm{P}$ & $\mathrm{P}$ & - \\
Uroleucon ambrosiae (Thomas) & - & $\mathrm{P}$ & - \\
Uroleucon pseudoambrosiae (Olive) & - & - & $\mathrm{P}$ \\
\hline 1P a present at location. & & &
\end{tabular}

${ }^{1} \mathrm{P}=$ present at location.

2* $=$ known vector of papaya virus.

civora, A. gossypii, A. illinoisensis, A. nerii, A. spiraecola, T. aurantii and $P$. nigronervosa, are known vectors of the papaya ring spot virus (Abreu, 1994; Vegas et al., 1986; Higa and Namba, 1971; Namba and Higa, 1981; Blackman and Eastop, 2000; Pantoja et al., 2002). Little is known about the vectoring capacity of the remaining species.

In Puerto Rico, the difference in species composition between the two locations is probably associated with differences in agricultural crops or weeds present at each location. Plantains and papaya are common crops at both sites and municipalities; however, large commercial papaya plantings are common in the Isabela area, whereas in Corozal plantain is the predominant crop, and papaya farms are small and spread out.

The presence of weeds might affect aphid densities in papaya fields (Villanueva and Peña, 1991) and is another possible explanation for the differences in aphid species composition among sites. Plantings at Corozal were almost weed free, whereas at Isabela weeds were common and abundant between the papaya rows with 24 species of plants from 22 genera and 11 families (Table 2). In Florida 13 plant species from 
TABLE 2. Weeds associated with papaya fields in Puerto Rico and Florida.

\begin{tabular}{|c|c|c|}
\hline \multirow[b]{2}{*}{ Family/Genus } & \multicolumn{2}{|c|}{ Percentage plants/square meter } \\
\hline & Isabela, PR & Florida $^{1}$ \\
\hline \multicolumn{3}{|l|}{ Amaranthaceae } \\
\hline Amaranthus spp. & 0.67 & 4.81 \\
\hline \multicolumn{3}{|l|}{ Commelinaceae } \\
\hline Commelina diffusa Burm.f. & 63.24 & $\mathrm{NP}^{2}$ \\
\hline \multicolumn{3}{|l|}{ Compositae } \\
\hline Bidens pilosa $\mathrm{L}$. & $<0.001$ & NP \\
\hline Emilia sonchifolia (L.) DC. & 0.17 & 4.47 \\
\hline Galinsoga spp. & 5.26 & NP \\
\hline Parthenium hysterophorus L. & 0.05 & 11.34 \\
\hline Vernonia cinerea (L.) Lessing & 0.05 & NP \\
\hline Wedelia trilobata (L.) Hitchc. & 17.85 & NP \\
\hline \multicolumn{3}{|l|}{ Convolvulaceae } \\
\hline Ipomoea quamoclit L. & $<0.001$ & NP \\
\hline Ipomoea spp. & 0.45 & NP \\
\hline \multicolumn{3}{|l|}{ Cyperaceae } \\
\hline Cyperus spp. & 0.67 & NP \\
\hline Unidentified spp. & NP & 1.03 \\
\hline \multicolumn{3}{|l|}{ Euphorbiaceae } \\
\hline Chamaesyce spp. & 0.17 & NP \\
\hline Chamaesyce serpyllifolia (Pers.) Small & NP & 0.69 \\
\hline Euphorbia graminea & NP & 0.69 \\
\hline Euphorbia heterophylla L. & 0.84 & NP \\
\hline \multicolumn{3}{|l|}{ Poaceae } \\
\hline Urochloa subquadripara (Trin.) R.D.Webster & 1.18 & NP \\
\hline Cynodon dactylon (L.) Pers. & NP & 3.44 \\
\hline Digitaria ciliaris (Retz) Koeler & NP & 0.69 \\
\hline Digitaria sanguinalis (L.) Scop. & 5.65 & NP \\
\hline Echinochloa colona (L.) Link & 0.22 & NP \\
\hline Eleusine indica (L.) Gaertn. & $<0.001$ & NP \\
\hline Paspalum fimbriatum HBK & NP & 1.03 \\
\hline Sorghum halepense (L.) Pers. & $<0.001$ & $\mathrm{NP}$ \\
\hline \multicolumn{3}{|l|}{ Leguminosae-Papilionoideae } \\
\hline Indigofera spicata Forsk. & NP & 1.03 \\
\hline Unidentified species & 0.28 & NP \\
\hline \multicolumn{3}{|l|}{ Leguminosae-Mimosoideae } \\
\hline Mimosa pudica L. & 0.50 & NP \\
\hline \multicolumn{3}{|l|}{ Malvaceae } \\
\hline Sida acuta Burm. f. & 0.62 & 32.30 \\
\hline Urena lobata L. & $<0.001$ & NP \\
\hline
\end{tabular}

${ }^{1}$ Four plants ( $17.9 \%$ of total could not be identified to family).

${ }^{2} \mathrm{NP}=$ not present at location. 
TABLE 2. (Continued) Weeds associated with papaya fields in Puerto Rico and Florida.

\begin{tabular}{llc}
\hline & \multicolumn{2}{c}{ Percentage plants/square meter } \\
\cline { 2 - 3 } Family/Genus & Isabela, PR & Florida $^{1}$ \\
\hline $\begin{array}{l}\text { Portulacaceae } \\
\quad \text { Portulaca oleracea L. }\end{array}$ & $\mathrm{NP}$ & 3.78 \\
$\begin{array}{l}\text { Oxalidaceae } \\
\quad \text { Oxalis corniculata L. spp. corniculata }\end{array}$ & $\mathrm{NP}$ & 4.81 \\
$\begin{array}{l}\text { Rubiaceae } \\
\text { Mitracarpus hirtus (L.) DC. }\end{array}$ & & $\mathrm{NP}$ \\
$\quad \begin{array}{l}\text { Richardia scabra L. } \\
\text { Urticaceae } \\
\text { Pilea microphylla (L.) Liebm. }\end{array}$ & 0.22 & $\mathrm{NP}$ \\
\hline
\end{tabular}

${ }^{1}$ Four plants ( $17.9 \%$ of total could not be identified to family).

${ }^{2} \mathrm{NP}=$ not present at location.

nine families were identified. Four plant species, Amaranthus spp., Emilia sonchifolia, Parthenium hysterophorus, and Sida acuta, were found in papaya fields in both Puerto Rico and Florida. The Malavaceae, Sida acuta, is a known host of $A$. gossypii (Martorell, 1976), one of the aphid species collected in both Puerto Rico and Florida and a known vector of virosis in papaya (Pantoja et al., 2002). However, little is known about the relationship between $A$. gossypii and $S$. acuta, or between the plant and the virus, thus suggesting the need to study the relationship between viruses affecting papaya and the weeds commonly found in papaya fields. Furthermore, little is known about the alternate hosts for most of the aphid species reported in this study. According to Plant Viruses on Line (2004) S. acuta is susceptible to viruses of economic importance to agriculture.

No aphids could be collected from papaya plants by using the DVac; however, the sampling technique was efficient collecting $A$. middletonii, A. spiraecola, and Hys. setariae and other unidentified species from weeds. Aphis middletonii was the only aphid species collected with both the D-Vac and water traps. It is concluded that the D-Vac is not an efficient sampling method for aphids on papaya plants; because of plant size and architecture it is difficult to reach the plant canopy with a D-Vac without destroying or affecting the plant. Another difficulty with the suction device is that the time required to complete a sample can be up to ten minutes per tree. In contrast, once the water pan trap is installed, servicing requires about one minute per trap. In addition, wingless aphids collected with the suction device are difficult to identify. 
Additional studies are needed to establish the vectoring capacity of the aphids collected in this study. A study is also needed on the biology, development, and preference of aphids for the weeds commonly found in papaya fields as well as a study of the relationship between viruses affecting papaya and the weeds commonly found in fields. The large number of species collected in this study (21), the difficulties in identifying species and vectors, and the lack of action thresholds suggest that for management purposes, future work should be directed toward correlating total number of aphids with virus reservoirs (either weeds or infested papaya plantings) near the plantings, rather than toward identifying aphid species in the field.

\section{LITERATURE CITED}

Abreu, E., 1994. Insectos de la papaya y prácticas de control. pp. 58-62 In: Memorias Foro: Cultivo, Producción y Manejo. Estación Experimental Agrícola de Puerto Rico, Recinto de Mayagüez, Univ. Puerto Rico, Aguadilla, Puerto Rico, 20 de mayo de 1994.

Adsuar, J., 1947a. Studies on virus diseases of papaya (Carica papaya) in Puerto Rico. I. Transmission of papaya mosaic. J. Agric. Univ. P.R. 31:248-256.

Adsuar, J., 1947b. Studies on virus diseases of papaya (Carica papaya) in Puerto Rico. II. Transmission of papaya mosaic by green citrus aphid (Aphis spiraecola Patch). J. Agric. Univ. P.R. 31:257-259.

Agricultural Experiment Station, 1987. Conjunto Tecnológico para la producción de papaya. Universidad de Puerto Rico, Recinto de Mayagüez. 16 pp.

Becerra-L., E. N., 1987. Dinámica poblacional y hospederas de áfidos vectores de virus de la mancha anular del papayo en Veracruz XIV. Congreso Nacional Fitopatología, Morelia Michoacán, México. p. 11.

Blackman, R. L. and V. F. Eastop, 2000. Aphids on the World's Crops. John Wiley \& Sons, New York, USA. 466 pp.

Hernández, E., 2001. Comportamiento del virus de la mancha anular del papayo, bajo tres sistemas de manejo en el cv. "Maradol Roja", en el municipio de Paso de Ovejas, Veracruz. Tesis, Colegio de Postgraduados, Instituto de Fitosanidad, Campus Veracruz, México. 93 pp.

Higa, S. Y. and R. Namba, 1971. Vectors of the papaya mosaic virus in Hawaii. Proc. Hawaiian Entomol. Soc. 21(1):93-96.

Ishii, M. and O. V. Holtzmann, 1963. Papaya mosaic disease in Hawaii. Plant Disease Reporter 47:947-951.

Khurana, P. and K. S. Bhargava, 1971. Three new vectors of papaya viruses. J. Horti. Sci. 46:209-211.

Martorell, L. F., 1976. Annotated Food Plant Catalog of the Insects of Puerto Rico. University of Puerto Rico, Agricultural Experiment Station, Río Piedras, PR. 303 pp.

Martorell, L. F. and J. Adsuar, 1952. Insects associated with papaya virus diseases in the Antilles and Florida. J.Agric. Univ. P.R. 45:863-869.

Namba, R. and C. Y. Kawanishi, 1966. Transmission of papaya mosaic virus by the green peach aphid. J. Econ. Entomol. 59:669-671.

Namba, R. and S. Y. Higa, 1981. Papaya mosaic transmission as affected by the duration of the acquisition probe of the green peach aphid- Myzus persicae (Sulzer). Proc. Hawaiian Entomol. Soc. 23 (3):491-494. 
Nariani, T. K., 1956. Leaf curl of papaya. Indian Phytopathology IX:151-155.

Pantoja, A., P. Follett and J. Villanueva, 2002. Pests of Papaya. pp. 131-156 In: Tropical fruit pests and pollinators, biology, economic importance, natural enemies and control, J. E. Peña, J. Sharp and M. Wysoki [eds.] CAB International, Wallingford, UK.

Plant Viruses on Line, 2004. http://image.fs.uidaho.edu/vide/famly082.htm\#Sida\%20acuta

Pontis, R. E., 1953. La virosis de la lechosa (Carica papaya) en Venezuela I. Transmisión del mosaico. Agronomía Tropical Venezuela 2:241-251.

Rabara, R. C., L. D. Valencia, A. C. Sumalde, N. B. Bajet and V. N. Villegas, 1996. Correlation between aphid abundance and ringspot virus disease incidence in papaya. Philippine J. Crop Sci. 21(1):58.

Robles, W., 2002. Efecto de las prácticas culturales sobre la incidencia de áfidos y virosis en papaya, Carica papaya L. Tesis de Maestría, Universidad de Puerto Rico, Mayagüez Campus, Mayagüez, PR

Schaefers, G. A., 1969. Aphid vectors of the papaya mosaic virus in Puerto Rico. J. Agric. Univ. P.R. 53:1-13.

Smith, C. F., L. F. Martorell and M. E. Pérez, 1963. Aphididae of Puerto Rico. Tech. Paper Univ. Agric. Exp. Stn. P.R. 37: 121 pp.

Vegas, A., M. Cermeli and G. Trujillo, 1986. Áfidos relacionados con el virus de la mancha anillada de la lechosa en Venezuela: Presencia, Transmisión y Eficiencia. Agronomía Tropical 35(1-3):21-31.

Villanueva, J. A. and R. Peña, 1991. Áfidos (Homoptera: Aphididae) colectados en "trampas amarillas de agua" en la planicie costera de Veracruz, México. Agrociencia Serie Protección Vegetal 2, 7-20.

Villanueva, B. and J. A. Villanueva, 1994. Transmisibilidad del "virus de la mancha anular del papayo" (VMAP) entre hospedantes, por medio de áfidos (Homoptera: Aphididae). XXIX Congreso Nacional de Entomología-Southwestern Branch Annual Meeting-Entomology Society of America. Abril 24-27. Monterrey, Nuevo León, México. p. 142.

Wolcott, G. N., 1933. An Economic Entomology of the West Indies. Caly and Sons Ltd., Bungay, Suffolk.

Wolcott, G. N., 1948. The Insects of Puerto Rico. J. Agric. Univ. P.R. 32:101-145. 